\title{
Prospects of agricultural business in the Republic of Tatarstan
}

\author{
Farit Mukhametgaliev*, Landysh Sitdikova, Marsel Khismatullin, Nail Asadullin, and Lilia Mikhailova
}

Kazan State Agrarian University, Kazan 420015, Russia

\begin{abstract}
The relevance of the study is defined by the need to identify problems and determine prospects for business development in the agrarian sphere of economy in the regions of Russia in the context of new challenges to external economic environment. The purpose of the paper is to develop recommendations on optimization of the state agrarian policy in the field of agricultural business development on the basis of analysis of the current situation and to identify trends in agriculture development of Russia and its regions. The novelty of the study is to identify trends in the development of agricultural business in the regions of Russia and to develop directions for improving the organization of efficient agricultural entrepreneurship in the Republic of Tatarstan. The paper presents the analysis of efficiency of agricultural business, identifies trends, problems and prospects for its development, defines priority directions for improving the organization of activities of agricultural business of the Republic of Tatarstan. Theoretical provisions and practical recommendations proposed in the paper can be applied in scientific research on the development of agricultural business, in scientific justification of main directions, methods and mechanisms for the implementation of the state agro-food policy. The practical significance of research results includes the possibility of using them in the development of agrarian policy, formation of effective mechanisms of state impact on the development of agro-food complex at federal and regional levels to achieve high targets.
\end{abstract}

\section{Introduction}

Successful activity of agricultural business in modern conditions is one of the priority directions of agroindustrial complex, both at the local level and at the level of the whole country, since it performs socially important functions by providing food to the population of Russia and employment of the society. At present, the problems of agricultural business development are of particular interest at all levels of the economy. It is largely explained by the fact that the development of the agro-industrial complex gained the status of one of the priority national projects, which tasks in the future shall lead to the growth of the agricultural sphere of economy [1-3]. The efficiency of agrarian business is a key task that solves the problems of food supply of the population, which is among the top priorities in achieving sustainable development of rural areas. The development of agrarian business strongly depends on natural and climatic conditions, natural and biological factors and market conditions. Due to its specificity, it is more investment-innovative and involves complex interaction of some economic factors within agro-food policy of the state. The main mechanism to implement agro-food policy priorities is development and effective functioning of agrarian business entities [4-7]. In this regard, it is critical to define trends, to identify development prospects and to improve the efficiency of agrarian business entities.

\section{Materials and methods}

The theoretical and methodological framework of the study is based on interaction and complementarity of fundamental provisions and the concept of economic theory. The theoretical and methodological framework also included the works of foreign and domestic agricultural economists, normative and legislative acts of the Russian Federation on the regulation of agro-food policy, materials of international and All-Russian scientific and practical conferences devoted to the development of agriculture.

The general methodological framework of the study contains the systemic analysis. The extensive data and the variety of its content led to different approaches, methods and techniques of scientific research of socioeconomic processes within the limits of system analysis, such as constructive, deterministic, retrospective, dynamic, statistical.

The study applied methods revealing trends in the development of agro-food policy and features of their manifestation: monographic, abstract-logical, calculation-constructive, economic-statistical, analogy.

Official data of the Federal Service of State Statistics of the Russian Federation, the Ministry of Agriculture of the Russian Federation, the Ministry of Agriculture and Food of the Republic of Tatarstan, planning and reporting documents of agricultural organizations, materials contained in monographs, dissertations and reports of research institutes, publications, materials of scientific conferences, expert assessments, data obtained

Corresponding author: fem59@mail.ru 
during author's analysis and calculations were used as the information and factual basis of the study.

\section{Results}

The Republic of Tatarstan is among the top three subjects of the Russian Federation in terms of gross agricultural products and to the full extent provides food to the population living in the territory of the Republic. The Republic occupies the land area of 6.8 million hectares, among which agrarian business entities possess 4.5 million hectares of farmland, including 3.4 million hectares of tilled area. As of the beginning of 2018 the population of the Republic of Tatarstan amounted to 3894 thousand people, the average annual number of employed in the economy of the region was 1952 thousand people, where the number of employed in the field of agriculture made 170 thousand people, which is $8.7 \%$ of the population. Agricultural business is presented by 15 thousand agricultural organizations with various forms of economy and property, more than 400 thousand personal auxiliary farms. About 40 dairy plants, 5 meat-packing factories and more than 100 meat processing workshops, 3 sugar plants are engaged in the processing of agricultural products. In 2017 the gross regional product of the Republic of Tatarstan amounted to 2115.5 billion rubles, with a growth rate of $2.8 \%$ compared to the previous year. Industry, agriculture and trade account for a significant share of gross regional product [8-11].

The share of agrarian business in the total structure of the gross regional product of the Republic of Tatarstan in 2017 amounted to $12.1 \%$, in previous periods the relative share of agricultural activity did not change significantly. In general, the volume of agricultural production in 2017 increased by $5.2 \%$ in comparable prices to the level of 2016 and amounted to 256.1 billion rubles. Table 1 shows the main development indicators of agrarian business.
According to the results of 2018, the volume of agrarian business products of all categories of agricultural producers amounted to 216.0 billion rubles (92.0\% to the level of 2017 in current prices). If we consider the dynamics of indicators for a longer period, the average annual growth rate of agrarian business of the Republic of Tatarstan for the last six years is $35 \%$, $\mathrm{t}$. and on average $5.8 \%$ per year, which shows the dynamic development of production in the agricultural sector of the economy. Agrarian business of the Republic of Tatarstan is constantly developing, which is facilitated by: natural and climatic conditions, positively directed state support, large investments in agriculture, etc. Occupying $2.3 \%$ of the agricultural land of Russia, today the Republic of Tatarstan produces $4.6 \%$ of agricultural products and is a self-sufficient region for food supply having significant potential to increase the export of agricultural food: the volume of exports of agricultural and food products abroad in 2017 amounted to 176 million dollars demonstrating an increase of 23 million dollars in relation to 2016, at the same time import amounted to 52 million dollars demonstrating an increase of 12 million dollars. Considering the performance indicators of agrarian business entities in crop production in 2018, regarding specific indicators of production the republic has ensured the necessary volumes of production [12-15].

Livestock production in agrarian business entities has a steady growth rate. At the same time, the efficiency of production of certain agricultural products remains low (Table 2).

In general, the results of agrarian business are profitable, except for the production of cattle meat, but the level of profitability does not exceed 10-12\%, which prevents extended reproduction on the basis of modernization of the material and technical base.

Table 3 shows the main performance indicators of large and medium-sized subjects of agrarian business of the Republic of Tatarstan.

Table 1. Main performance indicators of agrarian business entities over 2013-2018

\begin{tabular}{|c|c|c|c|c|c|c|c|c|}
\hline \multirow[t]{2}{*}{ Indicators } & \multirow[t]{2}{*}{2013} & \multirow[t]{2}{*}{2014} & \multirow[t]{2}{*}{2015} & \multirow[t]{2}{*}{2016} & \multirow[t]{2}{*}{2017} & \multirow[t]{2}{*}{2018} & \multicolumn{2}{|c|}{$2018, \%$} \\
\hline & & & & & & & 2017 & 2013 \\
\hline Gross agricultural output in current prices, bln rub & 160.2 & 186.0 & 217.1 & 233.7 & 235.3 & 216.0 & 92 & 135 \\
\hline incl. crop farming & 79.0 & 88.7 & 109.2 & 120.9 & 119.0 & 101.7 & 85 & 129 \\
\hline livestock business & 81.6 & 97.3 & 107.8 & 112.7 & 116.3 & 114.3 & 98 & 140 \\
\hline Volume index to the previous year - total, $\%$ & 98.6 & 102.9 & 104.9 & 104.3 & 105.0 & 97.1 & $\mathrm{x}$ & $\mathrm{x}$ \\
\hline incl. crop farming & 99.4 & 105 & 108.8 & 108.2 & 109.7 & 92.3 & $\mathrm{x}$ & $\mathrm{x}$ \\
\hline livestock business & 97.9 & 101.0 & 101.4 & 100.4 & 100.7 & 101.8 & $\mathrm{x}$ & $\mathrm{x}$ \\
\hline \multicolumn{9}{|c|}{ Production, thousand tons } \\
\hline Grain in weight after processing & 2611.5 & 3366.0 & 3367.7 & 4105.2 & 4868.2 & 3657.6 & 75 & 140 \\
\hline Potato & 1323.0 & 1315.8 & 1589.7 & 1440.7 & 1466.8 & 1189.6 & 81 & 90 \\
\hline Sugarbeet & 2109.8 & 1408.4 & 2011.8 & 2326.2 & 3100.2 & 2102.7 & 68 & 100 \\
\hline Vegetables & 329.4 & 357.0 & 385.3 & 400.9 & 405.2 & 327.7 & 81 & 99 \\
\hline Milk & 1712.2 & 1728.3 & 1753.7 & 1774.5 & 1823.8 & 1848.0 & 101 & 108 \\
\hline Cattle and poultry for slaughter (in body weight) & 477.2 & 465.9 & 468.8 & 486.2 & 491.6 & 502.2 & 102 & 105 \\
\hline Egg, mln pcs & 1073.0 & 1104.8 & 1170.6 & 1143.6 & 1187.5 & 1387.4 & 117 & 129 \\
\hline
\end{tabular}


Table 2. Efficiency of agricultural production in the Republic of Tatarstan

\begin{tabular}{|c|c|c|c|c|c|c|c|c|}
\hline \multirow[t]{2}{*}{$\begin{array}{l}\text { Type of product, } \\
\text { industry }\end{array}$} & \multicolumn{3}{|c|}{$\begin{array}{c}\text { Prime cost of } 1 \mathrm{c} \text {. of sold product, } \\
\text { rub. }\end{array}$} & \multicolumn{3}{|c|}{ Selling price of $1 \mathrm{c}$., rub. } & \multicolumn{2}{|c|}{$\begin{array}{c}\text { Level of } \\
\text { profitability, } \%\end{array}$} \\
\hline & 2017 & 2018 & $2018, \%$ to 2017 & 2017 & 2018 & $2018, \%$ to 2017 & 2017 & 2018 \\
\hline Grain & 577 & 715 & 124 & 627 & 800 & 128 & 8.7 & 11.9 \\
\hline Potato & 786 & 797 & 101 & 949 & 927 & 98 & 20.8 & 16.3 \\
\hline Sugarbeet & 147 & 173 & 118 & 170 & 186 & 109 & 15.6 & 7.6 \\
\hline Rapeseed & 1548 & 1726 & 111 & 1874 & 1891 & 101 & 21.1 & 9.5 \\
\hline Crop farming in general & $\mathrm{x}$ & $\mathrm{x}$ & $\mathrm{x}$ & $\mathrm{x}$ & $\mathrm{x}$ & $\mathrm{x}$ & 12.7 & 12.0 \\
\hline Milk & 1776 & 1770 & 100 & 2228 & 1943 & 87 & 25.4 & 9.8 \\
\hline Cattle meat & 13611 & 13919 & 102 & 10441 & 10813 & 104 & -23.3 & -22.3 \\
\hline Pork meat & 8307 & 8066 & 97 & 10888 & 11474 & 105 & 31.1 & 42.3 \\
\hline Poultry meat & 8841 & 8098 & 92 & 9967 & 8794 & 88 & 12.7 & 8.6 \\
\hline Egg (th.pcs) & 3713 & 3533 & 95 & 4312 & 4551 & 106 & 16.1 & 28.8 \\
\hline Livestock business in general & $\mathrm{x}$ & $\mathrm{x}$ & $\mathrm{x}$ & $\mathrm{x}$ & $\mathrm{x}$ & $\mathrm{x}$ & 10.0 & 6.3 \\
\hline
\end{tabular}

Table 3. Financial results of agrarian business entities of the Republic of Tatarstan

\begin{tabular}{|c|c|c|c|c|c|c|}
\hline Indicators & 2013 & 2014 & 2015 & 2016 & 2017 & 2018 \\
\hline Number of farms, items & 486 & 427 & 442 & 493 & 486 & 463 \\
\hline incl. profitable, items & 383 & 392 & 401 & 455 & 443 & 425 \\
\hline specific weight of profitable, $\%$. & 78.8 & 91.8 & 93 & 92 & 91 & 92 \\
\hline unprofitable, items & 103 & 35 & 41 & 38 & 43 & 38 \\
\hline specific weight of unprofitable, $\%$ & 21.2 & 8.2 & 7 & 8 & 9 & 8 \\
\hline Pretax profit, mln rub. & 2571.1 & 9834.8 & 12682.5 & 7755.2 & 7933.9 & 8826.5 \\
\hline Level of profitability, $\%$ & 4.5 & 16.2 & 17.4 & 9.4 & 9.6 & 10.1 \\
\hline Targeted financing and budget revenues, mln rub. & 12306.5 & 9837.4 & 13641.6 & 11662.4 & 10260.8 & 9581.2 \\
\hline Specific weight of budget revenues in cash, $\%$ & 21.1 & 15.8 & 16.7 & 12.7 & 11.5 & 10.3 \\
\hline
\end{tabular}

Table 4. Projects aimed at development of agrarian business in the Republic of Tatarstan over 2015-2018

\begin{tabular}{|c|c|c|c|}
\hline Name & $\begin{array}{l}\text { Investments, } \\
\text { mln rub. }\end{array}$ & $\begin{array}{c}\text { Number of } \\
\text { projects, items }\end{array}$ & $\begin{array}{c}\text { Commissioning of } \\
\text { new capacities }\end{array}$ \\
\hline Construction and modernization of dairy units & 3227.3 & 27 & 11500 heads \\
\hline Vegetable and potato storage facilities, fruit storage & 127.6 & 2 & 8 th. tons \\
\hline Greenhouse complexes & 389 & 2 & 2.1 ha \\
\hline Capital repair of dairy barns & 1681.6 & 352 & - \\
\hline Construction of silo-hay tranches & 204.5 & 129 & - \\
\hline Capital repair of vegetable and potato storage facilities & 166.7 & 28 & - \\
\hline Capital repair of machine and transport fleet & 33.4 & 14 & - \\
\hline Construction of access roads to family farms and animal production units & 200 & 32 & $25.4 \mathrm{~km}$ \\
\hline Others & 133.9 & 93 & - \\
\hline Total & 6164 & - & - \\
\hline
\end{tabular}

In recent years the republic extends its agrarian business entities thus reducing their total number, and in the last six years 23 farms were transformed by a merger of several into one large farm. During the analyzed period, the number of well-functioning agrarian business entities remains constant, in 2018425 (92\%) out of 463 farms were profitable. It shall be noted that targeted state support plays an important role here, due to which the level of profitability of the agricultural sector of the economy on average makes $10 \%$. Data show that without state financing of agrarian business the farms would be unprofitable.

Agrarian business of the Republic of Tatarstan is successful and efficient sphere of activity, the development of which requires permanent capital investments. With the state support over 2015-2018, the republic was able to implement projects thus contributing to higher performance of agrarian business entities (Table 4).

Thus, it is possible to note that the agrarian business of the Republic of Tatarstan tends to develop and improve the efficiency of its activity, since the calculation of the main indicators characterizing the performance of entrepreneurs revealed positive dynamics during the considered periods. The growth in the share of agrarian businesses in the total employed population and the share of gross products of the agro-industrial complex in the growth of gross regional product, as well as the increase in fund-raising, net and entrepreneurial income of agricultural organizations indicates the progress of agricultural entrepreneurship in Tatarstan.

Agrarian business of the Republic of Tatarstan has significant advantages in its production activities, which contributes to higher performance of agrarian business entities. The main problem of their effective 
development is lack of cooperative formations that would allow transferring the production to industrial technologies [16-19].

Key trends limiting progressive development of agriculture include the reduction of progressive impact of investments in agriculture within the framework of state programs in 2009-2012; lack of funds for current activities of agrarian business entities; suspension of investments in agriculture due to termination of foreign investments and unavailability of bank loans to agrarian business entities; absence of preconditions for sustainable development of agrarian business [20-22].

In this regard, the main objectives of agrarian business of the Republic of Tatarstan for the medium term are as follows: production of crop seeds; growth of construction complexes for storage and deep processing of agricultural products; construction of closed water supply facilities for fish and fish fry breeding in closed systems; production of raw milk deep processing products (dried baby food), lactose, phosphates, whey; construction of deep processing plants for the production of vegetable proteins and concentrates; construction of wholesale distribution centers [23, 24].

For these measures on the development of agriculture the republic has the following reserves: free and fertile land; excess raw materials (grain, legume, raw milk) and the need to increase the value added of products; import of products and the need to displace import deliveries, increase Russia's self-sufficiency, improve export of agricultural products of Tatarstan. At present the country is fulfilling projects that are expected in the near future (Table 5).

Table 5. Projects in progress aimed at the development of agrarian business in the Republic of Tatarstan

\begin{tabular}{|l|l|l|c|c|}
\hline \multicolumn{1}{|c|}{ Enterprise } & \multicolumn{1}{|c|}{ Project purpose } & $\begin{array}{c}\text { Project } \\
\text { duration }\end{array}$ & $\begin{array}{c}\text { Investments, } \\
\text { mln rub. }\end{array}$ & $\begin{array}{c}\text { Commissioning } \\
\text { of new capacities }\end{array}$ \\
\hline Chelna Broiler LLC & Poultry slaughter enterprise & $2017-2019$ & 4254.4 & 10500 heads/h \\
\hline Aznakai LLC & $\begin{array}{l}\text { Constriction of an animal production unit per 2000 } \\
\text { of dairy cows }\end{array}$ & $2018-2019$ & 1007 & $12000 \mathrm{t}$ per year \\
\hline APK Food Program LLC & Constriction of a cattle young-stock breeding farm & $2017-2019$ & 1250 & 10000 heads \\
\hline Phoenix LLC & Constriction of a pig-breeding complex & $2017-2019$ & 1087 & 65000 heads \\
\hline AijiesAgro LLC & Constriction of a gill fungi complex & $2018-2019$ & 1067 & $5600 \mathrm{t}$ per year \\
\hline LLC TC Maisky & Constriction of block glasshouses & $2018-2019$ & 921 & 5,14 ha \\
\hline Biosphere-Fish LLC & Constriction of sterlet fry breeding & $2017-2019$ & 625 & 5 mln items per year \\
\hline Zainsky Elevator LLC & Constriction of grain and oil crop storage elevator & $2017-2018$ & 1462.2 & $150000 \mathrm{t}$ \\
\hline ISC Chelnichlebproduct & Reconstriction of feed factory & $2017-2018$ & 488.2 & 30 t/h \\
\hline Miramol LLC & Constriction of dairy farm & $2017-2022$ & 2200 & 4800 milking herd \\
heads
\end{tabular}

All measures to develop agrarian business in Tatarstan are carried out within the framework of the state program Development of Agriculture and Regulation of Markets of Agricultural Products, Raw Materials and Food in the Republic of Tatarstan for 2013-2021.

According to this development program, the amount of resource allocation by years will amount to 182172,015 million rubles, including from the federal budget it is planned to attract $-81817,782$ million rubles, from the budget of the Republic of Tatarstan 96886,172 million rubles and from extra-budgetary sources it is planned to attract -3468.061 million rubles (Table 6).

Thus, the development of agricultural activity in the Republic of Tatarstan seems quite promising and has a considerable potential for further growth. At the state level, there is a favorable situation, which through the financing of the agricultural sector encourages agricultural entrepreneurs to develop their production enterprises, which will eventually affect the activities of the agricultural sector as a whole.
Table 6. Resource allocation for the development program by years

\begin{tabular}{|c|c|c|c|}
\hline \multirow{2}{*}{ Year } & \multicolumn{3}{|c|}{ Investments, mln rub. } \\
\cline { 2 - 4 } & $\begin{array}{c}\text { From the budget } \\
\text { of the Republic } \\
\text { of Tatarstan }\end{array}$ & $\begin{array}{c}\text { From the } \\
\text { federal } \\
\text { budget }\end{array}$ & $\begin{array}{c}\text { From extra- } \\
\text { budgetary } \\
\text { sources }\end{array}$ \\
\hline 2013 & 7821,363 & 11078,526 & 3,437 \\
\hline 2014 & 10387,324 & 9851,733 & 966,204 \\
\hline 2015 & 14863,995 & 11989,745 & 205,3 \\
\hline 2016 & 11862,463 & 10175,709 & 175,589 \\
\hline 2017 & 16038,935 & 8277,268 & 361,309 \\
\hline 2018 & 11172,012 & 6619,157 & 511,486 \\
\hline 2019 & 8237,355 & 5881,844 & 422,052 \\
\hline 2020 & 8237,355 & 5881,844 & 411,342 \\
\hline 2021 & 8251,363 & 8971,899 & 411,342 \\
\hline Total & 96886,172 & 81817,782 & 3468,061 \\
\hline
\end{tabular}

\section{Conclusion}

The analysis of economic development of agrarian business of the Republic of Tatarstan revealed the following problems: lack of effective markets for agricultural products; poor product quality; low efficiency of fixed assets; high moral and technical deterioration of fixed assets; high production cost. The agrarian business is 
an important factor in solving economic and social problems of the Republic of Tatarstan, such as: development of competitive agricultural environment, creation of new jobs in rural areas, increase of livestock and crop production, improvement of the quality of agricultural products, assistance to large agricultural enterprises by creating auxiliary or service industries, maintenance of innovative activity in terms of the introduction of new machines and technologies. Therefore, the organization and management of agrarian business in the Republic of Tatarstan represents a strategic task to create a stable position in the economy of the region. Today agricultural entrepreneurship in the Republic of Tatarstan holds firm positions based on effective organization and management for the purpose of promising strategic growth of the social and economic sphere. With a significant share in the structure of gross regional product, agrarian business shall be supported by the state at a high level.

The developed basic provisions significantly increase the efficiency of the main measures aimed at the creation of the state influence on the development of agrarian business, which, along with other measures, ensures the increase of production efficiency and positive solution of economic and social problems of the agro-industrial complex.

\section{References}

1. O.N. Kuznetsova, A.E. Melgui, Yu.A. Dvoretskaya, AIC: economics, management 8, 19-26 (2018)

2. E.V. Rudoy, S.V. Ryumkin, M.S. Petukhova, Achievements of Sci. and Techn. of Agro-Industrial Complex 10, 8-10 (2017)

3. A Battalova, O. Ignatjeva, IIOABJ 1, 28-31 (2019)

4. N.F. Kashapov, M.M. Nafikov, M.Kh. Gazetdinov, Sh.M. Gazetdinov, A.R. Nigmatzyanov, IOP Conf. Ser. Mat. Sci. and Engineering 412(1), 012038 (2018)

5. D.I. Faizrakhmanov, Grain Farm of Russia 2, 64-67 (2014)

6. O.N. Kuznetsova, A.E. Melgui, Yu.A. Dvoretskaya, AIC: economics, management 8, 19-26 (2018)
7. M. Zhemdinov, R. Gilfanov, S. Zhemdinov, O. Semicheva, J. of Kazan State Agrarian Univer. 2(44), 98-102 (2017)

8. A.I. Tikhomirov, AIC: Economy, Management 4, 42-51 (2018)

9. F.N. Mukhametgaliev, L.F. Sitdikova, F.F. Mukhametgalieva, F.N. Avkhadiev, Studies on Russian Economic Development 2, 162-165 (2019)

10. V.V. Maslova, M.V. Avdeev, I.I. Maslov, Economics of Agricultural and Processing Enterprises 9, 10-15 (2018)

11. M.-P. Menzel, D. Fornahl, Industrial and Corporate Change 1, 205-238 (2010)

12. A.A. Schutkov, Economics of Agricultural and Processing Enterprises 4, 2-6 (2017)

13. O.V. Kirillova, D.I. Faizrakhmanov, J. of Kazan State Agrarian Univer. 4, 28-30 (2015)

14. V.V. Maslova, N.A. Borkhunov, N.F. Zaruk, AIC: Economy and Management 4, 51-60 (2017)

15. I.G. Ushachev, V.V. Maslova, V.S. Chekalin, AIC: economics, management 11, 4-11 (2017)

16. V.M. Kosselev, A.V. Pohlyobkin, Economics of Agriculture of Russia 3, 64-70 (2018)

17. D.I. Faizrakhmanov, J. of Kazan State Agrarian Univer. 3, 39-55 (2015)

18. D.F. Khafizov, M.M. Khismatullin, J. of Kazan State Agrarian Univer. 3(50), 157-161 (2018)

19. A.K. Subaeva, A.A. Zamaidinov, Int. Business Management 7, 1780-1784 (2015)

20. O.V Kirillova, D.I. Faizrakhmanov, J. of Kazan State Agrarian Univer. 2, 49-53 (2015)

21. I.G. Ushachev, V.V. Maslova, V.S. Chekalin, AIC: Economics, Management 3, 4-12 (2018)

22. L.F. Sitdikova, F.N. Mukhametgaliev, Grain Farm of Russia 2, 68-71 (2014)

23. P.P. Pershukevich, L.E. Athaniev, AIC: economics, management 12, 34-53 (2017)

24. E.V. Rudoy, S.V. Ryumkin, M.S. Petukhova, Achievements of Science and Technology of AgroIndustrial Complex 10, 8-10 (2017) 